\title{
The Importance of the Informal Financial Market for Rural Development Financing in Developing Countries: The Example of Pakistan
}

\author{
WINFRIED MANIG
}

\begin{abstract}
The informal credit market is of crucial importance in the rural areas in Pakistan, even after decades of considerable development of formal credit organisations and of subsidised credit programmes by the government. This is due mainly to the fact that informal credit relations are embedded in the economic, political, and social interaction networks of the inhabitants in the rural areas. These interaction networks also maintain the direct credit costs and the transaction costs at a low level. However, the national development policy underestimates or even negates the significance of the informal financial market. Here, political action is required for initiating change.
\end{abstract}

\section{INTRODUCTION}

The lack of capital and the absence of attractive investment opportunities are considered to be important reasons behind inadequate economic development in many developing countries. This is why an attempt is made in most developing countries to encourage, through development policy measures, capital formation as well as the supply of financial means in the form of credit through official financial institutions. The hypothesis of a financial bottleneck thus has led to the establishment of credit systems predominated by the government to finance the necessary investments in urban and rural areas of most developing countries.

In Pakistan as well, specific government credit programmes have been implemented through the establishment of a formal system of credit organisations in the rural areas. In addition to the supply of mostly subsidised credits, it was necessary to establish a system of financial organisations in central places to guarantee their physical accessibility. Thereby, the expansion of the formal credit system itself was considered to be a component of the development process [von Pischke et al. (1983); Mittendorf (1987), pp. 6 ff.]. Does the expansion of the formal credit system actually satisfy the needs of potential customers? This question will be discussed by taking Pakistan as an example.

Winfried Manig is Professor at the Institute of Rural Development, University of Göttingen, Germany.

Author's Note: I am thankful to an anonymous referee of this journal for suggesting improvements in an earlier draft of this paper. 


\section{GOVERNMENT CREDIT POLICY}

In the past decades, the formal credit system has been expanded in the rural areas of Pakistan through the establishment of an infrastructure of credit organisations (banks, cooperatives, etc.) and with the help of special credit programmes oriented towards target groups. Thus, the conditions were created to guarantee the supply of credit to potential customers. Simultaneously, the possibilities of facilitating money-saving were also created so that a functioning rural financial market exists [Qureshi (1984); Berger (1986); Manig (1990); Fiege (1992)]. The following credit organisations that implement special programmes exist in the rural areas in Pakistan:

- Taccavi loans. In emergency situations, the government grants credit directly to farmers.

- Agricultural credit and multi-purpose cooperatives. Cooperatives provide credit facilities at a low rate of interest to their members, very often the influential members of the managing board.

- Agricultural Development Bank of Pakistan (ADBP). The ADBP chiefly allocates medium- and long-term credit to farmers, cooperatives, and the agricultural processing industry (agro-business loaning programme) for investments and means of production. Security for the credit is furnished by material collaterals or by two guarantors. This is why most of the borrowers have been land-owners. The loans were utilised chiefly for purchasing tractors, installing tube-wells, and buying mineral fertilizers. The access to loans at subsidised interest was barred to tenants and small owner-operators, even when special credit programmes were implemented.

- Government Commercial Banks. These banks (nationalised in 1974), since 1974, have been bound by the government 'Mandatory Credit Targets' to grant loans to farmers for purchasing production inputs. The banks concentrate their activities on the allocation of short-term loans, for which material collaterals must also be provided.

- The State Bank of Pakistan. It grants rediscount credit to commercial banks and cooperatives and has, to that end, opened up a special rural credit fund [Qureshi (1984), pp. $111 \mathrm{ff}$.$] .$

The banking system in the rural areas has been expanded considerably through the development of a network of branches. This applies mainly to the Punjab province which predominates in the economic sector. Thereby, the distribution of the regional offices and of the branches is subjected to the hierarchy of the settlement structure according to the Central Place Theory [Wanmali (1922), pp. 24 ff.]. Thus, in connection with the development of the communication infrastructure, the physical accessibility of the formal credit organisations is guaranteed to all rural inhabitants. 
In addition, since 1972, the banks have been employing the so-called 'Mobile Credit Officers' (MCOs) who deal with all the formalities of loan allocation. Of the approximately 45,000 villages in Pakistan, more than 30,000 are served by the ADBP and 16,000 by the commercial banks through their branches and the MCOs [Maan (1988)]. As a result of the 'Supervised Credit Schemes,' the loan conditions of all the banks regarding interest rate, security, and loan ceilings have been harmonised. Especially, the banking security requirements cause the scarce credits to be principally allocated to landowners since they can provide material collaterals (see also the recent survey carried out by Malik et al. (1996, pp. 269).

For short-term credits, two wealthy guarantors are required. For long-term credits, in contrast, the so-called 'Passbook System' was established. The landed property is recorded in the passbook which must be deposited with the lender. The interest rates are lower than those usually claimed on the market and are therefore subsidised by the government. Generally, in connection with the banking security requirements, this caused the scarce credits to be supplied only to specific rural inhabitants, namely, those who had at their disposal collaterals in the form of wealth and who, simultaneously, maintained good contacts with the staff of the bank. Thus, the traditional interpersonal relations network was transposed to the modern sector and predominates the activities.

Other groups who do not maintain these interactive relations, which definitely prevail according to the principle of reciprocity, either have no access to such credits or the costs of access are excessively high. Due to that system, the élite groups are in a position to use the progressive development potential, which is made available by the modern credit markets, to maintain and perpetuate their power. Indeed, this system is undergoing changes, and is following the trend intended by the government, although at a very slow pace. The subsidised loans provided to members of the rural élites (landowners, businessmen, etc.) are not used for rural activities relevant to development exclusively but are also misused with the help of complicated mechanisms.

\section{RURAL FINANCIAL MARKET}

So far as the actual credit financing in the rural regions is concerned, what is the situation in Pakistan following the good development of the formal system? For analysis, reference will be made to two extensive official statistical surveys on credit structure conducted in 1972 (published in 1984) and 1985 (published in 1989).

In 1972 (see Table 1), only 11 percent of the credit amounts borrowed by rural households was provided by formal credit organisations, mainly by the commercial banks and the ADBP. More than 89 percent of the credit was borrowed from informal sources; the principal lenders were friends and relatives who provided 
almost 58 percent of the credit amounts, followed by tradesmen who supplied 16 percent. If the number of loans is taken as a basis, only 7 percent came from formal sources.

Table 1

Distribution of Total Borrowings by Source and Type of Rural Household in Pakistan, 1972*

\begin{tabular}{|c|c|c|c|c|c|c|}
\hline Credit Source & $\begin{array}{c}\text { Owner } \\
\text { Operato } \\
\mathrm{r}\end{array}$ & $\begin{array}{c}\text { Owner- } \\
\text { cum- } \\
\text { Tenant }\end{array}$ & Tenant & $\begin{array}{c}\text { Owner } \\
\text { Non- } \\
\text { Operato } \\
\text { r }\end{array}$ & $\begin{array}{l}\text { Non- } \\
\text { Farm } \\
\text { HH }\end{array}$ & $\begin{array}{c}\text { All } \\
\text { Rural } \\
\text { HH }\end{array}$ \\
\hline \multicolumn{7}{|l|}{ Formal Sources } \\
\hline 1. Co-op Societies & 1.2 & 0.9 & 0.6 & 0.5 & 0.5 & 0.8 \\
\hline 2. Co-op Banks & 0.4 & 0.3 & 0.2 & 0.5 & 0.1 & 0.3 \\
\hline 3. ADBP & 7.7 & 3.3 & 1.0 & 2.7 & 0.0 & 3.7 \\
\hline 4. Commercial Banks & 4.2 & 1.0 & 0.9 & 17.1 & 6.2 & 5.3 \\
\hline 5. Taccavi & 0.9 & 0.4 & 0.1 & 0.2 & 0.1 & 0.4 \\
\hline 6. Unclassified & 0.3 & 0.2 & 0.2 & 0.2 & 0.1 & 0.2 \\
\hline Sub-total & 14.7 & 6.1 & 3.0 & 21.2 & 6.9 & 10.7 \\
\hline \multicolumn{7}{|l|}{ Informal Sources } \\
\hline 7. Friends + Relatives & 61.9 & 68.9 & 50.1 & 52.0 & 57.3 & 57.8 \\
\hline 8. Money-lenders & 2.3 & 2.1 & 1.9 & 6.7 & 1.6 & 2.4 \\
\hline 9. Landowners & 1.7 & 5.4 & 34.9 & 0.4 & 5.1 & 8.1 \\
\hline \multicolumn{7}{|l|}{ 10. Commission Agents/ } \\
\hline Merchants & 15.5 & 12.8 & 7.3 & 11.1 & 23.4 & 16.2 \\
\hline 11. Factories & 1.1 & 0.4 & 0.1 & 0.6 & 0.6 & 0.7 \\
\hline \multirow[t]{3}{*}{ 12. Unclassified } & 2.8 & 4.3 & 2.7 & 8.0 & 5.1 & 4.3 \\
\hline & 85.3 & 93.9 & 97.0 & 78.8 & 93.1 & 89.3 \\
\hline & 100 & 100 & 100 & 100 & 100 & 100 \\
\hline
\end{tabular}

Source: Qureshi et al. (1984), p. 158.

*According to the Credit Survey conducted in 1973.

In 1985 (see Table 2), the formal credit had increased to a range of about 29 percent, especially as a result of the extension of the ADBP credits. Accordingly, the informal credit decreased to approximately 73 percent. Thereby, the loans obtained from friends and relatives and from tradesmen continued to predominate. Simultaneously, from 1972 to 1985, the nominal amounts of credits had increased from 3,700 million to 28,000 million Pakistani rupees.

In the future, as a result of the increasing commercialisation of all economic sectors in Pakistan's rural areas, the importance of formal institutionalised credit organisations will undoubtedly continue to grow. This applies particularly when large investments are to be financed by loans. Here, the informal credit market is usually overburdened. 
Table 2

Distribution of Total Loans by Source and Type of Rural Household in Pakistan, 1985*

\begin{tabular}{|c|c|c|c|c|c|}
\hline Credit Source & $\begin{array}{c}\text { Owner } \\
\text { Operator }\end{array}$ & $\begin{array}{l}\text { Owner- } \\
\text { cum- } \\
\text { Tenant }\end{array}$ & Tenant & $\begin{array}{c}\text { Non- } \\
\text { Farm HH }\end{array}$ & $\begin{array}{c}\text { All Rural } \\
\text { HH }\end{array}$ \\
\hline \multicolumn{6}{|l|}{ Formal Sources } \\
\hline 1. Co-op Societies & 1.9 & 2.1 & 0.7 & 0.7 & 1.5 \\
\hline 2. ADBP & 29.4 & 26.3 & 1.0 & 4.0 & 20.3 \\
\hline 3. Commercial Banks & 5.8 & 5.1 & 2.2 & 1.8 & 4.5 \\
\hline 4. Taccavi & 0.1 & 0.1 & 0.0 & 0.0 & 0.1 \\
\hline 5. Others & 0.4 & 0.0 & - & 0.1 & 0.3 \\
\hline Sub-total & 37.5 & 33.6 & 4.0 & 7.0 & 26.7 \\
\hline \multicolumn{6}{|l|}{ Informal Sources } \\
\hline 6. Friends + Relatives & 46.0 & 40.1 & 35.2 & 76.2 & 49.1 \\
\hline 7. Money-lenders & 1.4 & 1.3 & 1.0 & 1.4 & 1.3 \\
\hline 8. Landowners & 1.0 & 6.2 & 45.9 & 2.2 & 8.1 \\
\hline \multicolumn{6}{|l|}{ 9. Commission Agents/ } \\
\hline Merchants & 12.3 & 17.6 & 12.9 & 9.2 & 12.7 \\
\hline 10. Factories & 1.2 & 0.8 & 0.5 & 2.3 & 1.2 \\
\hline 11. Others & 0.6 & 0.5 & 0.5 & 1.8 & 0.8 \\
\hline Sub-total & 62.5 & 66.4 & 96.0 & 93.0 & 73.3 \\
\hline Total & 100 & 100 & 100 & 100 & 100 \\
\hline
\end{tabular}

In the case of informal credit, those supplied by friends and relatives predominated in 1972 and 1985 and this applies to all the groups of rural borrowers of credit. Landowners, too, borrow the largest volume of their credit from friends and relatives. In 1985, the share of non-agricultural rural households had increased considerably in comparison with 1972. For tenants, the landowners are traditionally important credit suppliers (cf. Tables 1 and 2). The opposite of the informal credit market is the informal saving of rural inhabitants. However, this will not be discussed at this stage. Here, the structure of the informal credit of rural households in Pakistan will not be dealt with in detail [see Manig (1990)]. The interesting aspect, in contrast, is the general reasons for the predominance of informal credit despite the good infrastructure of the formal credit organisations and the existence of appropriate credit programmes orientated towards target groups, on the one hand, and the neglect and negation of the informal market by development experts, on the other hand. 


\section{INFORMAL CREDIT MARKET}

Why does the informal credit market have such a great significance in the rural areas in developing countries and why has it been neglected by development experts? The discussion of the special features of informal credit should help to answer these questions [cf. also the various arguments in Adam and Fitchett (1992)].

Informal credit relations between lenders and borrowers in Pakistan are just as in other developing countries, embedded in the people's economic, political, and social network of personal relations. Credit relations are only one component of a multi-stranded network of interactions between people. Since there are hardly any professional money-lenders in Pakistan, credit is very rarely the main purpose of interactive relations and has very often the complementary character of relations predominated by other aims (kinship, friendship, neighbourhood, economic, and political relations). Usually, these relations already existed before credit was taken and will still be maintained after the loan has been repaid. Thus, credit relations as such are not immediately identifiable and are perceived by those concerned only as a subordinate activity and not even considered as loans.

The application of the New Institutional Economics Approaches to the informal credit relations shows that, as a result of the personalised interaction networks, the insecurities and bilateral shortage of information between lenders and borrowers can be reduced considerably. The embedding of credit relations in other economic and social interactions (e.g., marketing, tenancy, friendship, kinship, etc.) enhances at the same time the trust between the participants [Floro and Yotopoulos (1991), pp. 108].

So far as credit is concerned, the principle of reciprocity applies to economic, political, and social relations. This principle of reciprocity and the very often complementary character of informal credit implies that, when he grants credit, the lender expects and receives something which is marked by the predominating relation. In the case of relations predominated by politics, the return service can consist of loyalty and support in political disputes; in the case of relations of an economic nature, a trader, for example, secures for himself the marketing of the borrower's products or a landowner seeks the guarantee of tenancy relations with the borrower. Very often, various motives overlap in the case of informal credit relations. The principle of reciprocity has also an effect in the case of friends and relatives since it is expected that the lender also receives support in specific situations. The individual credit relations and the possible motives will not be analysed at this stage [see, for Pakistan, Manig (1990), pp. 209 ff.; for India, Bouman (1989); for various developing countries, Adams and Fitchett (1992)].

The informal credit relations do not refer to supply but to demand, and are, therefore, adjusted to the borrower's specific circumstances and individual requirements regarding modalities, amount, and terms. Thus, credit is available 
wherever and whenever it is required. It is also determined by the participants' role expectations. In Pakistan, usually, no interest is claimed for informal credit. Having been proscribed during the re-Islamisation process, interest rates have altogether lost their importance. Taking into account conditions under which professional moneylenders dominate the informal credit market, the existence of formal institutional credit organisations may reduce the interest rates altogether. For Pakistan, however, this is important to a limited extent only.

On the whole, all the credit costs, including the lenders' and borrowers' direct transaction costs, are likely to be lower in the case of informal credit relations than on the formal market. The transaction costs include the costs of information supply, enquiry, negotiation, agreement, control, risk and insecurity assessment, guarantee, control and enforcement of the agreements as well as the regulation of conflicts. Since a network of personal relations predominated by other aims exists between borrowers and lenders, and since credits are only one (very often only complementary) interaction, only marginal additional transaction costs arise in the case of credit relations. This applies especially to small amounts of credit. In contrast, all the transaction costs for maintaining the multi-stranded economic, political, and social relations network in rural societies in developing countries are likely to be high (mutual obligations, dependencies, gifts, and parties to maintain the relations, etc.). However, it is difficult to quantify transaction costs [Pollak (1985), p. 606] and to attribute them to the individual interactions. On the formal credit market, in contrast, all the credit costs (despite the fact that the interest rates are much lower due to government subsidy) are very high, especially for rural households that require low amounts of credit, and have no material collaterals as a result of high costs of access and lack of other relations.

Raising a loan on the informal market usually substantiates the borrower's personal dependence and, emotionally, a certain degree of inferiority vis-à-vis the lender. This is likely to be an important reason why élite groups try to avoid appearing on the informal credit market as borrowers. However, owing to their social position in a rural society they cannot afford to fail as creditors. The grant of this credit also substantiates then the borrower's loyalty.

The informal credit relations in the rural areas in Pakistan that exist as a component of a complex network of human interaction, as probably in many other developing countries, are difficult of access for a scientific analysis. This could surely be considered to be an important reason for unawareness and ignorance. Another important reason is undoubtedly the fact that available cash in traditional rural societies also increases the social obligation of lending this cash to members of the group in times of crisis or to help relatives. This is why products are only sold when cash is actually required for specific purposes. This is difficult to perceive for outsiders and fosters the notion that there is a general lack of capital. On the other 
hand, these credit relations are altogether marred by the prejudice that they are exploitative. This leads undoubtedly to a considerable underestimation of its significance for the development of the rural society, especially in view of attaining the mass of small farmers and of the informal rural sector as a whole. When attractive investment opportunities exist and technologies are divisible, informal credit sources are surely of considerable importance for financing development, as examples from many countries have shown during the period of the 'Green Revolution'.

As the increased importance of the formal credit market in Pakistan between 1972 and 1985 has shown, in the process of societal development and, therefore, in institutional change, the multiple personalised relations structures in the easily graspable village system orientated towards institutions that have different functions and specialised institutions. Indeed, very often the old relations are maintained parallel to modern institutions. This applies at present to the credit system in most of the developing countries. Since modern institutions such as the formal-legal credit markets still do not fulfil their function satisfactorily, traditional relations structures, such as informal credit, are justified in development policy. Therefore, the informal credit market must assume an important function when the economy attains a specific development level. The formal and the informal sectors complement each other and do not compete with each other. However, the traditional informal credit market is underestimated so far as its function in the social development progress is concerned, and even discriminated against.

\section{CONCLUSIONS FOR CREDIT POLICY}

As the example of Pakistan shows, the importance of the formal credit market is overestimated regarding its role in financing development. This is also undoubtedly due to the fact that there is considerable unawareness of informal credit. If the informal credit market is availed of at all, then very often in the extreme cases when exploitative structures exist. The importance of supplying formal credit is likely to be greatly overestimated especially for the group of disadvantaged marginal farmers, as even in the case of special credit programmes the target groups are only reached within the framework of the prevailing societal modes of distribution (land tenure, social system, power structure). Sufficient credit is no longer available to the actual target groups because funds are scarce. However, this diversion, which is termed 'market imperfections of the credit institutions' in the appropriate literature, is actually only the effect of the existing societal modes of distribution.

The informal rural credit market is very heterogeneous and is always a component of the prevailing political, economic, and social relations network, involving relatively low additional transaction costs for credit supply. In north-west Pakistan, in the 1960s, the informal credit market was mainly relevant only for sectors that were not directly productive and through which the expenditure for 
social obligations was met. In the meantime, however, directly productive investments are financed through this market [Fiege (1992), pp. 56 f.] since the informal credit market is much more appropriate to satisfy the credit needs of a large number of small farmers as multiple and differentiated sources exist, the supply is available everywhere, the conditions are very variable, and credit is simply a component of the comprehensive socio-economic relations network of the society. The latter advantage, precisely, is of considerable significance as a stabilising factor for marginal farmers at the time of critical social change. Thus, the traditional informal credit market also contributes, through the extension of the financing function of technological change, towards preventing a too considerable expansion of social polarisation in the modernisation process. Indeed, functioning ability is an indispensable prerequisite. On the other hand, social differences increase.

The significance of informal credit relations for financing investment is being increasingly acknowledged by empirical surveys and by the former's inclusion in theoretical concepts [cf. Adams et al. (1984); Seibel and Marx (1987); Adams and Fitchett (1992); Meyer and Nagarajan (1992); Murshid (1992); Bardhan (1989)]. Therefore, it is important to proceed from the fact that, with regard to saving formation and loans, the formal and the informal sectors complement each other and should thus be considered as a whole.

In general, the effectiveness of establishing a formal credit system to satisfy the actual credit requirements within a short term is largely overestimated, at least insofar as the aim is to reach the lower agricultural income groups, since the government's distribution policy bypasses the needs of small farmers in the prevailing societal modes of distribution in the rural areas. On the other hand, the informal credit market is underestimated. That is why, in terms of development policy, it would be worth considering whether a dualistic agricultural credit system (formal and informal credit market) should be promoted during a period of transition until the formal institutions become fully effective. This means strengthening the informal credit system in view of improving competition, transparency, and refinancing possibilities. The restricted informal sector only allows limited financial transactions. Refinancing through the formal institutionalised system, therefore, definitely will be a development measure of financial policy worth considering. Thus, a judicious contribution can be made towards the intended institutional change in rural societies.

\section{REFERENCES}

Adams, D. W., and D. A. Fitchett (1992) Informal Finance in Low-income Countries. Boulder, Col.

Adams, D. W., D. H. Graham and J. D. von Pischke (eds) (1984) Undermining Rural Development with Cheap Credit. Westview Special Studies in Social, Political, and Economic Development, Boulder and London. 
Bardhan, P. (ed) (1989) The Economic Theory of Agrarian Institutions. Oxford.

Berger, M. (1986) Agrarkredit in Pakistan. Struktur der Kreditversorgung punjabischer Landbewirtschafter. Socioeconomic Studies on Rural Development 69. Aachen.

Bouman, F. J. A. (1989) Small, Short and Unsecured. Informal Rural Finance in India. Delhi, Oxford, New York.

Fiege, U. (1992) Changes in the Credit System in North West Pakistan. In W. Manig Rural Institutional Development and its Impact in Northwest-Pakistan. Socioeconomic Studies on Rural Development 88: 50-59. Aachen.

Floro, S. L., and P. A. Yotopoulos (1991) Informal Credit Markets and the New Institutional Economics: The Case of Philippine Agriculture. Boulder, San Francisco and Oxford.

Maan, A. H. (1988) Farm Finance and Agricultural Development: Pakistan. Tokyo: Asian Productivity Organisation. 451-462.

Malik, S. J., S. S. Broca, and M. A. Gill (1996) Access by Farm Households to Credit from Formal Sources: The Case of Pakistan. In Quarterly Journal of International Agriculture 35:3 269-280.

Manig, W. (1990) Formal and Informal Credit Markets for Agricultural Development in Developing Countries-The Example of Pakistan. In Journal of Rural Studies 6:2 209-215.

Meyer, R. L., and G. Nagarajan (1992) An Assessment of the Role of Informal Finance in the Development Process. In G. H. Peters, B. F. Stanton and G. J. Tyler (eds) Sustainable Agricultural Development: The Role of International Cooperation. Proceedings of the Twenty-first International Conference of Agricultural Economists held at Tokyo, Japan, 22-29 August 1991. Dartmouth. 644-656.

Mittendorf, H. J. (1987) Promotion of Viable Rural Financial Systems for Agricultural Development. In Quarterly Journal of International Agriculture 26:1 6-27.

Murshid, K. A. S. (1992) Informal Credit Markets in Bangladesh Agriculture: Bane or Boon? In G. H. Peters, B. F. Stanton and G. J. Tyler (eds) Sustainable Agricultural Development: The Role of International Cooperation. Proceedings of the Twenty-First International Conference of Agricultural Economists held at Tokyo, Japan, 22-29 August 1991. Dartmouth. 657-668.

Pakistan, Government of (1989) Pakistan Rural Credit Survey 1985. Final Report. Lahore: Agricultural Census Organisation.

Pischke, J. D. von, D. W. Adams and G. Donald (1983) Rural Financial Markets in Developing Countries. Their Use and Abuse. Baltimore and London.

Pollak, R. A. (1985) A Transaction Cost Approach to Families and Households. In Journal of Economic Literature 23:2 581-608. 
Qureshi, S. K. et al. (1984) Pakistan Rural Credit Survey. Vol. I: Analytical Report, Vol. II: Technical Report. Pakistan Institute of Development Economics and State Bank of Pakistan.

Seibel, H. D., and M. T. Marx (1987) Dual Financial Markets in Africa. Case Studies of Linkages between Informal and Formal Financial Institutions. Kölner Beiträge zur Entwicklungsländerforschung 2: Saarbrücken, Fort Lauderdale.

Wanmali, S. (1992) Rural Infrastructure, The Settlement System and Development of the Regional Economy in Southern India. Washington, D. C.: IFPRI. (Research Report 91.) 